\title{
Crop Response to Soil Acidity Factors in Ultisols and Oxisols in Puerto Rico. VIII. Yams ${ }^{1,2}$
}

\author{
Fernando Abruña, José Vicente-Chandler and \\ José A. Rodriguez-García ${ }^{3}$
}

\begin{abstract}
The effect of various soil acidity factors on yield and foliar composition of yams (Dioscorea alata L) were determined in two Ultisols and an Oxisol. The yam cultivar Smooth Statia responded strongly to variations in soil acidity in the two Ultisols. Yields decreased sharply as \% Al saturation of the effective cation exchange capacity of the soil increased. Relative yields dropped to about $60 \%$ of maximum when $\mathrm{Al}$ saturation was only about $10 \%$, and to $20 \%$ of maximum when Al saturation was $50 \%$, a level common among Ultisols of Puerto Rico. The high sensitivity of this crop to soil acidity is shown by the fact that yields were sharply reduced when pH dropped from 5.6 to 5.1, a level at which most crops show little or no response to liming. Foliar composition was not affected by soil acidity, except that $\mathrm{Ca}$ content decreased with decreasing soil $\mathrm{pH}$ and increasing Al saturation. Yields of cultivar of the same species as Smooth Statia and known locally as Name de Palo were not affected by soil acidity levels in an Oxisol.
\end{abstract}

\section{INTRODUCTION}

Yams are an important source of carbohydrates for millions of people throughout the humid tropics. They produce high yields. An average crop yielding $12 \mathrm{t} / \mathrm{ha}$ has about 22 million calories compared with 9 million produced by an average crop of corn yielding $2,500 \mathrm{~kg} / \mathrm{ha}$ in the tropics (8).

Despite the importance of yams as a food crop only limited research information is available on yam production and most of that is concerned with cultivars and planting systems $(4,7,12)$. Information on the effects of soil acidity on yam production is largely limited to tropical Africa under shifting cultivation. Under these conditions, Nye and Greenland (10) in East Africa found a small response by yams to liming after 8 years of continuous farming of an Oxisol with a pH of around 6.0 in the savanna zone.

The present study was undertaken to determine the effect of soil acidity factors on yields and foliar composition of yams grown on two Ultisols and an Oxisol in Puerto Rico.

${ }^{1}$ Manuscript submitted to Editorial Board September 2, 1982.

${ }^{2}$ This paper covers work carried out cooperatively between the Agricultural Research Service, USDA and the Agricultural Experiment Station, College of Agricultural Sciences, Mayagüez Campus, University of Puerto Rico.

${ }^{3}$ Soil Scientist, Soil Scientist ARS-USDA, and Assistant Agronomist, Agricultural Experiment Station, College of Agricultural Sciences, Mayagüez Campus, University of Puerto Rico, Río Piedras, P.R. 


\section{MATERIALS AND METHODS}

The study was conducted on plots with widely varying levels of soil acidity resulting from differential applications of limestone over a period of years.

One site was on Corozal clay (Aquic Tropudults), another on a Corozal clay subsoil (top soil removed 15 years ago), and one on Coto sandy clay (Tropeptic Haplorthox).

TABLE 1.-Effect of soil acidity factors on yield and foliar composition of yams grown on two Ultisols and one Oxisol of Puerto Rico

\begin{tabular}{|c|c|c|c|c|c|c|c|c|c|c|}
\hline \multicolumn{4}{|c|}{ Soil acidity factor } & \multirow{2}{*}{ Yield } & \multicolumn{6}{|c|}{ Leaf Contents } \\
\hline $\mathrm{pH}$ & $\begin{array}{l}\text { Exchangeable } \\
\mathrm{Al}\end{array}$ & $\begin{array}{c}\text { Exchangeable } \\
\mathrm{Ca}+\mathrm{Mg}\end{array}$ & $\begin{array}{c}\mathrm{Al} \\
\text { sat. }\end{array}$ & & $N$ & $\mathrm{P}$ & $\mathrm{K}$ & $\mathrm{Ca}$ & $\mathrm{Mg}$ & $\mathrm{Mn}$ \\
\hline \multicolumn{11}{|c|}{$\begin{array}{l}\text { t/ha } \\
\text { Corozal clay }\end{array}$} \\
\hline 5.90 & 0 & 15.12 & 0 & 21.2 & 3.10 & .10 & 2.11 & 1.68 & .42 & 224 \\
\hline 5.10 & 1.17 & 7.51 & 13 & 11.7 & 3.20 & .11 & 2.10 & 1.66 & .51 & 275 \\
\hline 4.90 & 2.36 & 7.52 & 23 & 9.8 & 3.10 & .12 & 2.28 & 1.62 & .43 & 172 \\
\hline 4.75 & 3.46 & 5.04 & 39 & 3.0 & 3.00 & .10 & 2.15 & 1.59 & .50 & 188 \\
\hline 4.60 & 5.65 & 5.25 & 50 & 4.0 & 2.90 & .09 & 2.09 & 1.57 & .42 & 117 \\
\hline 4.30 & 8.13 & 3.96 & 65 & 3.9 & 2.93 & .10 & 2.24 & 1.39 & .43 & 212 \\
\hline 4.15 & 10.91 & 2.08 & 81 & 1.1 & 2.93 & .10 & 1.92 & 1.17 & .40 & 203 \\
\hline \multicolumn{11}{|c|}{ Corozal clay-subsoil } \\
\hline 5.60 & 0 & 9.92 & 0 & 18.8 & 3.04 & .12 & 2.22 & 1.56 & .48 & 144 \\
\hline 5.05 & .58 & 8.82 & 6 & 11.8 & 3.13 & .09 & 2.46 & 1.46 & .51 & 126 \\
\hline 4.80 & 2.84 & 8.12 & 25 & 5.9 & 3.00 & .10 & 2.15 & 1.42 & .51 & 136 \\
\hline 4.60 & 4.42 & 5.73 & 42 & 6.7 & 2.99 & .10 & 2.00 & 1.44 & .43 & 148 \\
\hline 4.50 & 5.94 & 5.08 & 52 & 3.9 & 3.15 & .11 & 1.95 & 1.36 & .48 & 153 \\
\hline 4.25 & 7.38 & 3.73 & 64 & 1.6 & 3.12 & .12 & 2.02 & 1.37 & .41 & 164 \\
\hline 4.10 & 10.06 & 2.03 & 81 & 1.6 & 2.92 & .09 & 1.98 & 1.12 & .34 & 160 \\
\hline \multicolumn{11}{|c|}{ Coto sandy clay } \\
\hline 5.70 & 0 & 4.06 & 0 & 26.6 & 3.15 & .06 & 3.19 & 1.30 & .37 & 613 \\
\hline 5.05 & .26 & 3.15 & 7 & 27.8 & 3.02 & .06 & 3.16 & 1.33 & .37 & 646 \\
\hline 4.75 & .59 & 3.08 & 15 & 27.7 & 3.25 & .06 & 3.64 & 1.35 & .38 & 734 \\
\hline 4.60 & .78 & 2.60 & 21 & 26.2 & 3.22 & .06 & 3.17 & 1.48 & .33 & 760 \\
\hline 4.40 & 1.44 & 2.60 & 33 & 24.3 & 3.35 & .06 & 3.31 & 1.45 & .41 & 760 \\
\hline
\end{tabular}

There were thirty $4 \times 4$-m plots at each of the two Corozal sites and 40 plots on the Coto soil. All plots were surrounded by ditches to prevent runoff from one plot to another. In the spring of 1977 the Corozal sites were planted to the yam cultivar Smooth Statia, and the Coto site to a yam cultivar of the same species known locally as Ñame de Palo (1).

Tuber sections weighing about $200 \mathrm{~g}$ each were planted in hills at $1 \times$ $0.5 \mathrm{~m}$. Wire trellises $2 \mathrm{~m}$ high were provided to support the vines. All plots were fertilized with $500 \mathrm{~kg} / \mathrm{ha}$ of a 10-5-20 fertilizer, containing 30 
$\mathrm{kg} / \mathrm{t}$ of a mixture of $6 \% \mathrm{Mg}, 7.7 \% \mathrm{Mn}, 4.8 \% \mathrm{Cu}, 7 \% \mathrm{Fe}, 8 \% \mathrm{Zn}$ and $2.5 \%$ $\mathrm{B}$, at planting and again 5 months later. The plants were sprayed monthly with a fungicidal solution to control leaf spot caused by a species of Colletotrichum.

Samples consisting of young mature leaves were taken from plants in the center row of each plot 6 months after planting. The leaves were washed with distilled water, dried at $70^{\circ} \mathrm{C}$ and analyzed for $\mathrm{N}$ by the Kjeldahl method; for P, colorimetrically; for K, by flame photometry;/ for $\mathrm{Mn}$, colorimetrically as permanganate after oxidation with $\mathrm{KIO}_{4}$; and for $\mathrm{Ca}$ and $\mathrm{Mg}$ by the Versenate method (5).

The soil in each plot was sampled 2 months after planting; ten borings were taken at $0-15-\mathrm{cm}$ depths. The samples were air dried and passed through a 30-mesh screen. Exchangeable $\mathrm{Ca}, \mathrm{Mg}, \mathrm{K}$ and $\mathrm{Mn}$ were extracted with normal neutral $\mathrm{N} \mathrm{NH}_{4} \mathrm{OAc}$. Potassium was determined by flame photometry; $\mathrm{Ca}+\mathrm{Mg}$ by the Versenate method (5); and $\mathrm{Mn}$, colorimetrically as permanganate after oxidation with $\mathrm{KIO}_{4}$. Exchangeable $\mathrm{Al}$ was extracted with $\mathrm{N} \mathrm{KCl}$ and determined by the double titration method (9). Percentage Al saturation of the soil was calculated by considering the sum of exchangeable $\mathrm{Ca}+\mathrm{Mg}+\mathrm{K}+\mathrm{Al}+\mathrm{H}$ as the effective cation exchange capacity of the soil (6). Soil reaction was measured in a 1:1.5 soil to water ratio with a glass electrode $\mathrm{pH}$ meter.

Yield of tubers in each plot was determined when the plants matured, about 10 months after planting.

Data on yield and foliar composition was related to the various soil acidity factors by regression analysis.

\section{RESULTS AND DISCUSSION}

\section{COROZAL CLAY SOIL}

Yields of yams were sharply reduced by even fairly low levels of exchangeable $\mathrm{Al}$ in the soil (table 1 and figure 1). Furthermore, yields were depressed by about $50 \%$ when pH dropped from 5.9 to 5.1 (table 1, figure 1), a level at which most crops show little or no response to liming. Yields were only $19 \%$ of maximum at $50 \% \mathrm{Al}$ saturation and plants barely grew at the highest level of acidity.

Regression analysis of the data shows that all the soil acidity factors were highly correlated with yield (table 2).

Foliar composition was not affected by soil acidity factors, except that $\mathrm{Ca}$ content of the leaves decreased with increasing acidity (table 1). Phosphorus content of the leaves was low at all soil acidity levels, an indication that even high $\mathrm{Al}$ levels in the soil did not affect $\mathrm{P}$ solubility, or else requirements of yams for this nutrient are very low. 


\section{COROZAL CLAY SUBSOIL}

Somewhat lower yields were obtained in the Corozal soil than in the subsoil at all acidity levels (table 1).

The effect of the soil acidity factors on yields was similar to those occurring in the Corozal soil. Yields decreased with decreasing $\mathrm{pH}$ and increasing $\mathrm{Al}$ saturation of the soil (table 1, figures 1 and 2). At $\mathrm{pH} 4.6$

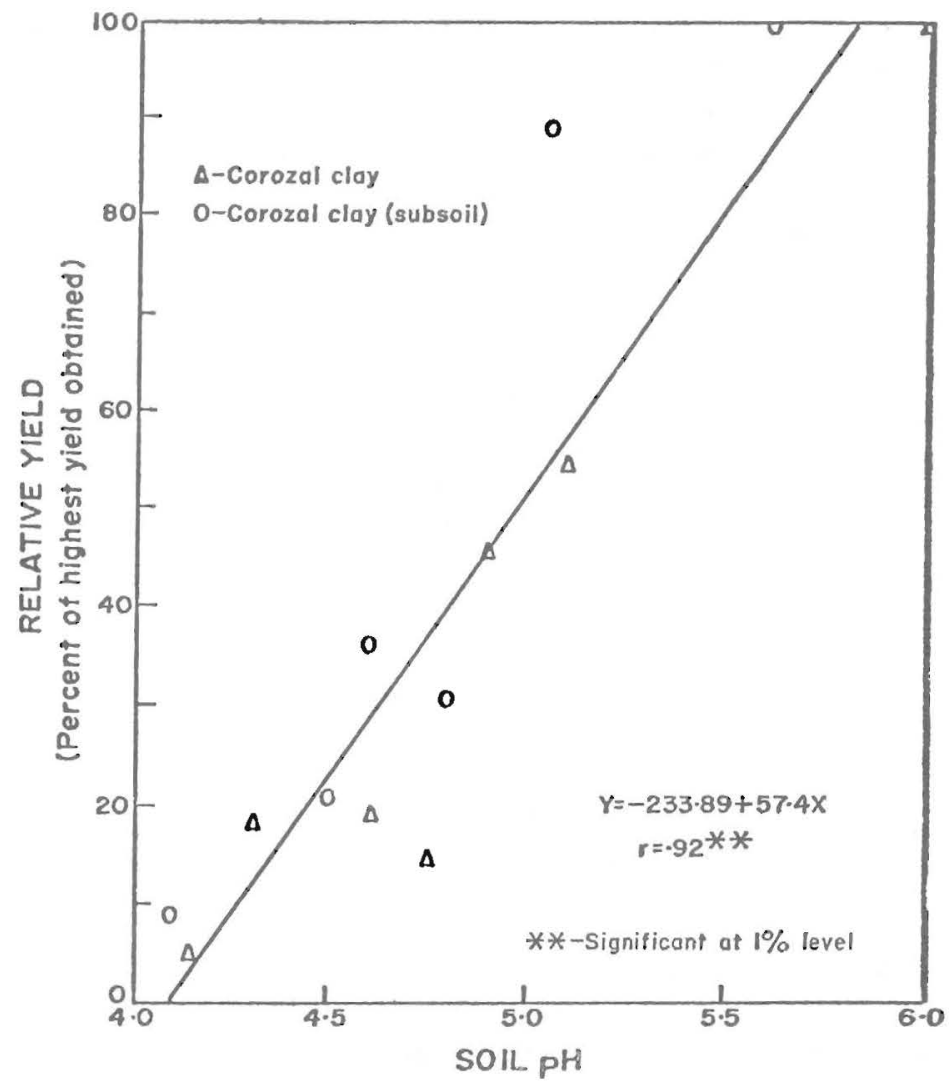

FIG. 1.- Relationship between $\mathrm{pH}$ of Corozal soil and subsoil (Ultisols) and relative yields of yam cultivar Smooth Statia.

with $\mathrm{Al}$ saturation of $56 \%$, a level very common in Ultisols of the tropics, yams produced only about $20 \%$ of maximum yields. This $20 \%$ figure compares with $68 \%$ of maximum yields produced by sweet potatoes on this site at this soil acidity level as determined by Abruña et al. (3).

Regression analysis of the data shows that all soil acidity factors were highly correlated with yields (table 2). Best correlations were obtained with $\mathrm{pH}$ and percent $\mathrm{Al}$ saturation of the soil. 
Chemical composition of the leaves was not significantly affected by soil acidity levels except for Ca content, which decreased consistently as soil acidity increased. This drop in Ca content of the leaves is similar to that reported by Abruña et al. (2) for corn grown on this subsoil, although corn was more tolerant to high acidity levels than yams are.

\section{COTO SANDY CLAY}

The yam cultivar Name de Palo was tolerant to the soil acidity levels in the Coto soil. At the lowest acidity level ( $\mathrm{pH}$ 5.7) yields of Name de Palo on the Coto soil were about $25 \%$ higher than those produced by Smooth Statia on Corozal clay. Soil pH as low as 4.4 together with $33 \%$

TABLE 2.-Relationships between soil acidity factors and yield of yams grown on two Ultisols and one Oxisol in Puerto Rico

\begin{tabular}{lcc}
\hline \multicolumn{1}{c}{ Soil Acidity Factors $(\mathrm{X})$} & \multicolumn{2}{c}{ Yield $(\mathrm{kg} / \mathrm{ha})(\mathrm{Y})$} \\
& $\mathrm{Y}=34.4+8.7 \mathrm{X}$ & $r=.72^{* *}$ \\
$\mathrm{pH}$ & $\mathrm{Y}=19.2-.50 \mathrm{X}+.0036 \mathrm{X}^{2}$ & $r=.82^{* *}$ \\
Al saturation $(\%)$ & $\mathrm{Y}=12.9-7.43 \mathrm{X}+.99 \mathrm{X}^{2}$ & $r=.70^{* *}$ \\
Exch. Al/exch. bases & $\mathrm{Y}=1.6+2.24 \mathrm{X}$ & $r=.89^{* *}$ \\
Exch. Ca $+\mathrm{Mg}$ & $\quad$ Corozal clay subsoil & $r=.83^{* *}$ \\
$\mathrm{pH}$ & $\mathrm{Y}=47.6+11.79 \mathrm{X}$ & $r=.83^{* *}$ \\
$\mathrm{Al}$ saturation $(\%)$ & $\mathrm{Y}=18.4-.42 \mathrm{X}-.0026 \mathrm{X}^{2}$ & $r=.79^{* *}$ \\
Exch. Al/each bases & $\mathrm{Y}=15.1-10.23 \mathrm{X}+1.53 \mathrm{X}^{2}$ & $r=.72^{* *}$ \\
Exch Ca $+\mathrm{Mg}$ & $\mathrm{Y}=2.9-2.72 \mathrm{X}$ & \\
& $\quad$ Coto sandy clay & \\
pH & Non significant & \\
$\mathrm{Al}$ saturation & Non significant & \\
Exch. Al/exch. bases & Non significant & \\
Exch. Ca & Non significant & \\
Exch. Ca $+\mathrm{Mg}$ & Non significant & \\
\hline
\end{tabular}

Al saturation did not decrease significantly yields of Ňame de Palo (table 1).

Increasing acidity of Corozal clay to this level resulted in a decrease in yields from about 21 to $4 \mathrm{t} / \mathrm{ha}$. Abruña $(2,3)$ has reported less marked effect of acidity factors in Oxisols than in Ultisols on yields of various crops.

Regression analysis of the data (table 2) shows that there were no significant correlations between yields of cultivar Ñame de Palo and soil acidity factors in the Coto soil.

Soil acidity did not affect the chemical composition of the leaves. Phosphorus content of the leaves of variety Name de Palo was extremely low, whereas $\mathrm{K}$ content was considerably higher, and $\mathrm{Ca}$ and $\mathrm{Mg}$ contents somewhat lower than those of Smooth Statia cultivar. Manganese con- 
tent was high at all soil acidity levels. The Coto soil, as well as many other Oxisols in Puerto Rico, has a higher content of both exchangeable and easily reducible $\mathrm{Mn}$, and a higher ionic activity of this element than Corozal clay as well as other Ultisols at similar soil $\mathrm{pH}$ levels (11).

The ameliorated effect of soil acidity on yams growing in Coto (Oxisol) as compared to that in Corozal (Ultisol) soil may be explained by a higher

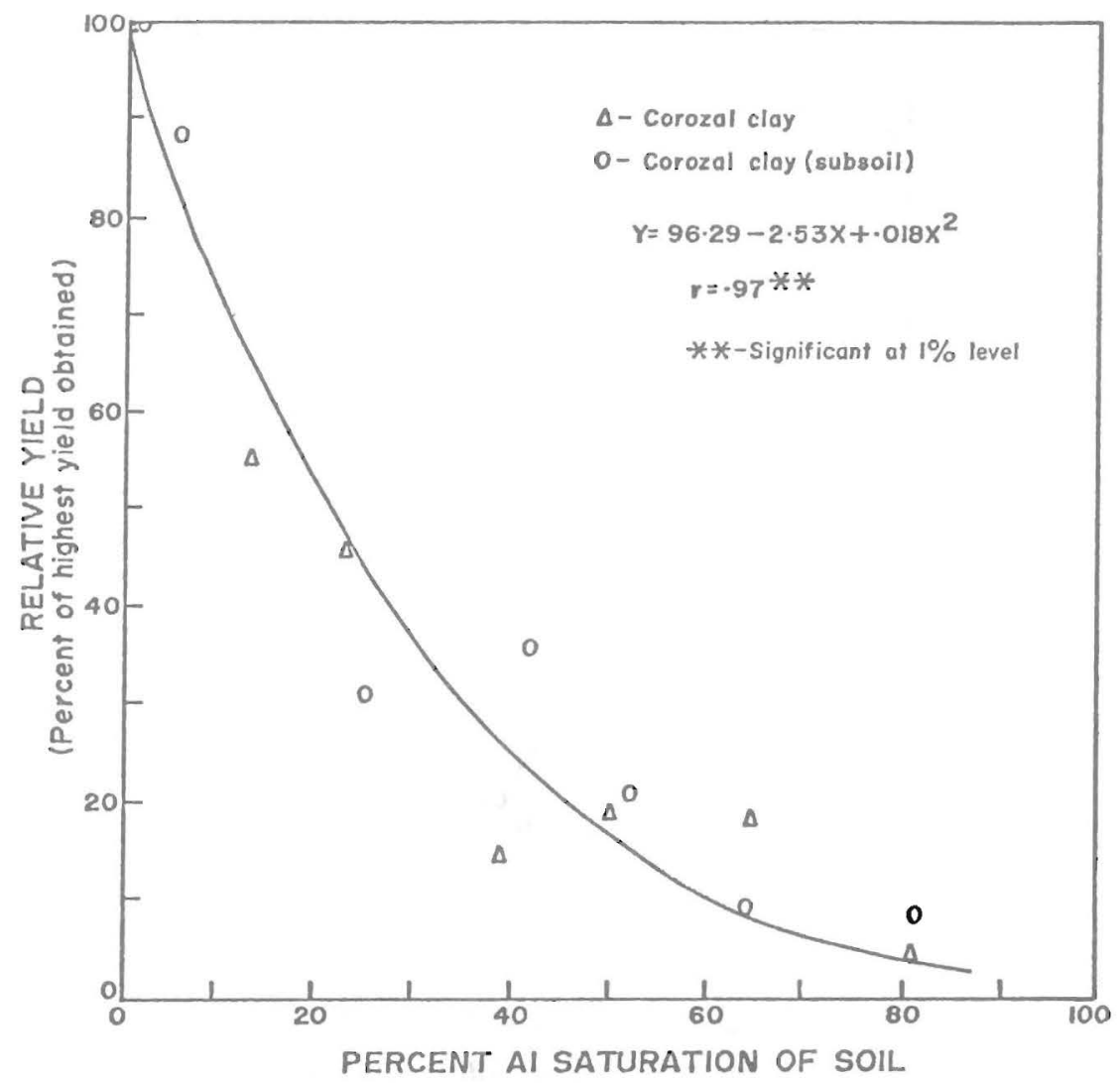

FIG. 2.-Relationship between percent Al saturation of the exchange capacity of Corozal soil and subsoil (Ultisols) and relative yields of yam cultivar Smooth Statia.

tolerance to acidity of Name de Palo cultivar or by less activity of $\mathrm{Al}$ in the former soil. Abruña (3) has suggested that the strong activity of the $\mathrm{Mn}$ in Coto clay reduces $\mathrm{Al}$ activity in such a way that crops sensitive to Al toxicity but tolerant to $\mathrm{Mn}$ respond less to liming on this soil than on Corozal.

Regression analyses of the combined data for the Corozal soil and subsoil (figures 1, 2,3) show that the cultivar Smooth Statia is very 
sensitive even to low levels of soil acidity. Only about $20 \%$ of maximum yields would be expected when $\mathrm{pH}$ drops to about 4.5 and $\mathrm{Al}$ saturation of the soil is about $50 \%$. As a matter of fact these acidity levels are common among Ultisols in Puerto Rico. Maximum yields were attained only when $\mathrm{pH}$ exceeded 5.5 and yields dropped to about half when $\mathrm{pH}$ dropped to the neighborhood of 5.0.

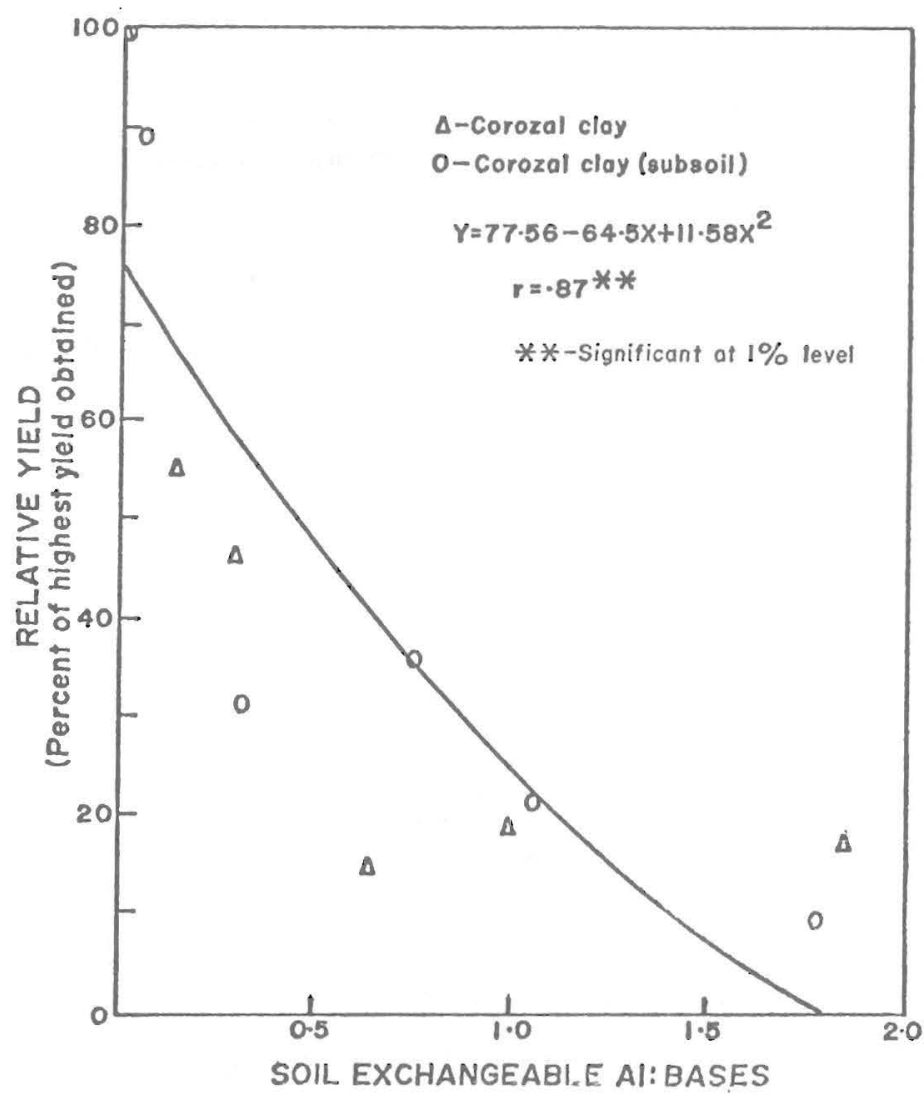

FIG. 3.- Relationship between Al/base ratio of a Corozal soil and subsoil (Ultisols) and relative yields of yam cultivar Smooth Statia.

\section{RESUMEN}

Se estudió el efecto de los factores de acidez en los rendimientos y composición foliar de dos variedades de ñame en dos Ultisol y un Oxisol típicos de extensas regiones tropicales.

Los rendimientos de la variedad Smooth Statia (Dioscorea alata L.) creciendo en dos Ultisol disminuyeron señaladamente según aumentó la 
acidez del suelo. Los rendimientos bajaron a alrededor de un $60 \%$ del máximo cuando la saturación del suelo con Al cambiable fue de aproximadamente $10 \%$, bajando hasta sólo un $20 \%$ de la producción máxima cuando la saturación con Al cambiable alcanzó el 50\%, grado de acidez muy común en los Ultisol de Puerto Rico. La producción máxima sólo se logró cuando el pH sobrepasó 5.5 y bajó a cerca de la mitad cuando la acidez alcanzó un pH de 5.0, nivel al cual muchas cosechas se aproximan a su máxima capacidad de producción, lo cual señala la sensitividad de los ñames a la acidez del suelo.

La composición foliar no se afectó por la intensidad de la acidez del suelo, excepto que el contenido de Ca disminuyó a medida que aumentaba la acidez.

La variedad conocida localmente como Ñame de Palo mostró ser tolerante a la acidez en un suelo Coto (Oxisol) arcilloso.

\section{LITERATURE CITED}

1. Abruña, F., Diaz, N. and Vicente-Chandler, J., 1981. Studies on management of a wild yam (Dioscorea alata) and a wild tanier (Xanthosoma sp.), J. Agric. Univ. P.R. 64 (1): 59-61.

2. Abruña-Rodríguez, F., Pérez-Escolar, R., Vicente-Chandler, J., Pearson, R. W. and Silva, S., 1974. Response of corn to acidity factors in eight tropical soils, J. Agric. Univ. P.R. 58 (1): 59-77.

3. - Vicente-Chandler, J., Rodriguez, J., Badillo, J. and Silva, S., 1979. Crop response to soil acidity factors in Ultisols and Oxisols in Puerto Rico. V. Sweet potato, J. Agric. Univ, P.R. 63 (2): 250-67.

4. Caro-Costas, R., Boneta, E. and Silva, S., 1968. The effect of various cultural practices on yield of yams in Puerto Rico, J. Agric. Univ, P.R. 52 (4): 356-61.

5. Cheng, K. L. and Bray, R. H., 1951. Determination of calcium and magnesium in soil and plant material, Soil Sci. 72: 449-58.

6. Coleman, N. T., Weed, S. B. and McCraken, K. J., 1959. Cation-exchange capacity and exchangeable cations in Piedmont soils of North Carolina, Soil Sci. Soc. Am. Proc. 23: 146-49.

7. Doku, E. U., 1967. Root crops in Ghana. In Proc. Int. Symp. on Trop. Root Crops. Univ. West Indies, St. Augustine, Trinidad.

8. Jacoby, T., 1965. Green Bulletin: Tropical root crops, Fiji Islands.

9. McLean, E. O., 1965. Aluminum. Methods of Soil Analysis. Am. Soc. Agron. Agron. Series 9 (Part 2): 994-96.

10. Nye, P. H. and Greenland, D. J., 1960. Commonwealth Bureau of Soils. Tech. Comm. 51, England.

11. Pearson, R. W., Pérez-Escolar, R., Abruña, F., Lund, Z. F. and Brenes, E. J., 1977. Comparative response of three crop species to liming several soils of the Southeastern United States and of Puerto Rico, J. Agric. Univ. P.R. 61 (3): 361-82.

12. Torto, J. O., 1956. The cultivation of yams in the Gold Coast, New Gold Coast Farmer 1: 6-8. 